Financial Risk and Management Reviews

2021 Vol. 7, No. 1, pp. 36-49.

$\operatorname{ISSN}(e): 2411-6408$

$\operatorname{ISSN}(p): 2412-3404$

DOI: 10.18488/journal.89.2021.71.36.49

(C) 2021 Conscientia Beam. All Rights Reserved.

check for
updates

\title{
MODELING AND ESTIMATION OF CUMULATIVE ABNORMAL RETURN USING VECM
}

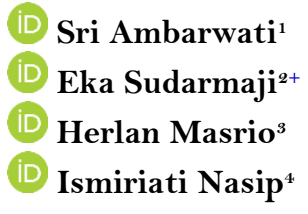

$+2$

Article History

Received: 24 June 2021 Revised: 30 July 2021

Accepted: 19 August 2021

Published: 21 September 2021

\section{Keywords \\ VECM \\ Characteristics \\ IPO \\ CA5D \\ CA30D \\ Macroeconomics}

JEL Classification:

C10, G10, G41.

\author{
${ }^{1,2, s}$ Fakultas Ekonomi and Bisnis, University of Pancasila, Jalan Srengseng \\ Sawah, Pasar Minggu Jakarta, Indonesia. \\ 'Email:sriambarwati@univpancasila.ac.idTel:081282688334 \\ ${ }^{2}$ Email: esudarmaji@univpancasila.ac.idTel:087884964643 \\ ${ }^{s}$ Email:herlan@uniopancasila.ac.idTel:0816946278 \\ 'Bina Nusantara University, Indonesia. \\ ${ }^{4}$ Email: ismiriati.nasip@binus.ac.idTel:08121085535
}

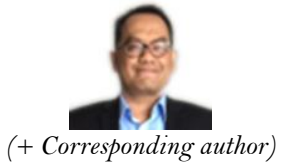

(+ Corresponding author)

\section{ABSTRACT}

This paper examined how firm-level idiosyncratic risk varies over time. It affected initial public offering (IPO) in the presence of pump-and-dump and flipping trends during the early trading of IPO stocks in the Indonesia Stock Exchange. The paper used the IPO data taken from 181 companies during the year 2015-2019. It revisited the relationship between Cumulative Abnormal Return thirty-days (CAR30D) and Cumulative Abnormal Return five-days (CAR5D) and the Characteristics (IPO Floating shares, IPO Fund and Price) and Macroeconomics Condition (Inflation rate). It also used the cointegration analysis and VECM model. The paper found that Both LnFloat and LnPrice had causal evidence in the long-run causality or short-run with Cumulative Abnormal Return thirty days (CAR30D). We also noted that idiosyncratic risk exposure depends on IPO characteristics. It was crucial for firms going public in hot-issue markets, undervalued IPOs, and high idiosyncratic-risk issues. The model suggested that those series should cointegrate firstly. However, the variable of LnIPOF und had causal evidence in the short-run causality only.

Contribution/Originality: This paper expected to fill the gap and confirmed what IPO characteristics and macroeconomics variables were significant and could predict that the IPO categorized into hot-issue markets, undervalued IPOs, and high idiosyncratic-risk issues.

\section{INTRODUCTION}

The theoretical model's explanation is simple: IPO anomalies generally include underpricing, long-term underperformance, and hot issue/cold issue based on the assumption that the investor is rational, and the average company or underwriter of the stock is not mistaken on IPO share price valuation. Practical explanations that IPO anomalies happened due to price stabilization by companies/underwriters resulted in irrationality/overreaction from investors. Therefore, this research created a model and estimated Cumulative Abnormal Returns for thirty days (CAR30D) and Cumulative Abnormal Returns for five days (CAR5D) to find an explanation of IPO anomalies in Indonesia by using the VECM. The model captured ideas behind IPO stock anomalies offered in the Indonesian capital market.

Phenomena IPO started when the initial return rate of IPO was positive (high) and sometimes unfavorable. The phenomenon was usually related to Phenomena listing stocks in demand/not in demand (Hot/Cold). This IPO initial return rate cycle occurred when some IPO stocks surge significantly due to phenomena underpricing. 
However, the movement of IPO stocks would then tend to underperform in the market in its long-term performance. There were always stock price movements that were much worse. The general explanation of underpricing IPO was based on the irrationality and overreaction of investors. Unfortunately, it did not provide an economic reason why they failed to behave rationally and why investors consistently always overreact.

A sample of stock price indexes or composite indexes was taken from companies listed on the Indonesia Stock Exchange. The number of companies that had already conducted an IPO was obtained from the Indonesia Stock Exchange. It consists of primary-board and emerging-board between January 2015 and December 2019. The authors selected several external and internal variables as two naturally different variables. VECM's econometric methodology was used to test the $\mathrm{AR}=0$ hypothesis for each IPO share already listed on IDX.

Authors combined company returns, calculated using the average abnormal return: AARt $=(1 / \mathrm{N}) \Sigma \mathrm{i} A R \mathrm{t}, \mathrm{t}$, and the average abnormal return, used AARt $=(1 / \mathrm{N}) \quad \sum \mathrm{i}$ ARi,t and the average abnormal return, used $\mathrm{AR}_{\mathrm{jt}}=\mathbf{R}_{\mathrm{jt}}-\overline{\mathbf{R}}_{\mathrm{j}} \mathrm{d}$. While some companies' CAR or Cumulative Abnormal Return values, used formulas (AAR)

- Average abnormal return or $\operatorname{AAR}_{t}=\frac{\sum_{j=1}^{N} A_{j t}}{N}$ cumulative abnormal return (CAR) $\operatorname{CAR}_{T_{1}, T_{2}}=\frac{\sum_{j=1}^{N} \sum_{t=T_{1}}^{T_{2}} \operatorname{AR}_{j t}}{N}$.

Meanwhile, the Initial Return (IR) calculation on the first day of listing used $\mathrm{IR}=\left(\mathrm{LnR}_{\mathrm{ij}} / \mathrm{LnR}_{\mathrm{ijt}-1}\right)$. IPOs with oversupply or high demand got a positive initial return on a positive average, while oversupply, IPOs experienced negative initial returns. A good proxy for oversupply was the level of oversupply and trading volume on the secondary market; the more significant the oversupply, the greater the total shares bought and sold immediately on the secondary market. The empirical literature had shown that macroeconomic factors and the frequency of IPOs were in a relationship. Therefore, we presented the following hypothesis: we wanted to test that the VECM might explain the relationship between endogenous factors or the company's characteristics. The exogen factors or 'Macroeconomic' factors with the thirty-day Cumulative Abnormal Return (CAR30D) and the five-day Cumulative Abnormal Return (CAR5D) were examined.

\section{LITERATURE REVIEW}

In recent years, IPO research had also occurred and increased with the taking of capital market research in several developing countries such as China (Chang, Chen, Chi, \& Young, 2008; Chen \& Kao, 2006; Mok \& Hui, 1998; Tian, 2011), India (Bansal \& Khanna, 2012; Deb \& Mishra, 2009), New Zealand (Vos \& Cheung, 1992), Bangladesh (Islam, Ali, \& Ahmad, 2010), Indonesia (Indriani \& Marlia, 2013; Manurung, Juwono, \& Siswanti, 2019; Manurung \& Manurung, 2019) and more. The launch of new IPO capital markets such as REIT and Listed Property Trust (LPT) had also become very popular to discuss in the literature (Bairagi \& Dimovski, 2011; Chen \& Lu, 2006; Dimovski, 2010) in it about Phenomena 'flipping' (Bayley, Lee, \& Walter, 2006; Dimovski, 2010) There was a link between idiosyncratic risk and IPO return rates. The idiosyncratic risk was often used to measure information asymmetry (Campbell \& Taksler, 2003). Some empirical studies (Beaulieu \& Bouden, 2020; Fu, 2009) found a positive relationship between volatility and idiosyncratic risk. The authors argued that investors need high premiums to hold idiosyncratic risky stocks. However, Arena, Haggard, and Yan (2008) and Ang, Hodrick, Xing, and Zhang (2006) showed negative relationships in their findings. Ang et al. (2006) explained pricing that stocks with high idiosyncratic risks were more sensitive to market volatility risks, thus lowering the return rate. VidalGarcía, Vidal, and Nguyen (2016) also highlighted the importance of idiosyncratic risk factors in determining IPO performance in European markets. Therefore, they noted that more portfolios (especially in Spain and the Netherlands) contained positively idiosyncratic risks, whereas all portfolios were very damaging in the UK. Beaulieu and Bouden (2020) found that idiosyncratic risk at the firm level positively affected the IPO's return in the 
case of the IPO. This paper investigated whether IPO-specific risks were essential in IPO pricing, given the high asymmetry of information occurring within the first 30 days of stock IPO trading.

\section{METHOD \& DATA}

The authors built a model Vector Error Correction (VECM). VECM was used to estimate and predict the future value of potential cumulative abnormal returns (CAR) on IPO stocks. VAR \& VECM served to analyze the innovative structure of the IPO model. Based on this VECM model, the authors tried to prove and identify dynamic relationships of endogenous and exogen variables within the IPO model.

First, several testing stages checked the root unit to see the behavior of time series economic data. It could be seen as the initial step in constructing a time series model, whether the data used stationary or not, which could be achieved using the dickey-fuller augmented test (Dickey \& Fuller, 1979) Secondly, test the cointegration and causality of granger temporal were using the maximum probability approach of Johansen (1988); lastly, the third stage included replacing VECM and testing its exogenity variables. The process of forming VECM could be seen in Figure 1.

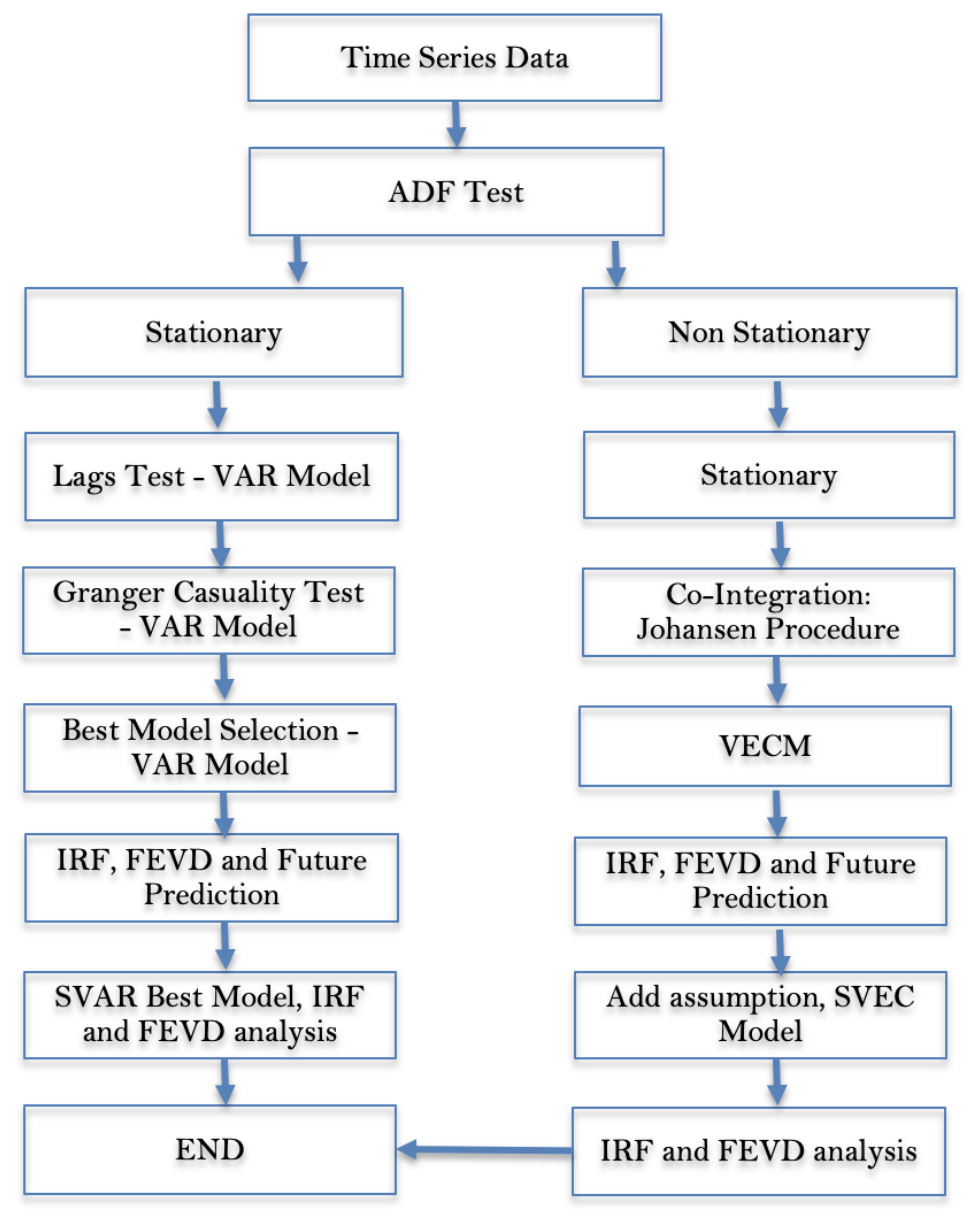

Figure-1. Var and VECM model correction process.

The VAR model explained the endogenous alteration of past data with other endogenous. VAR model parameters predicted using Ordinary Least Square (OLS) or the smallest square method. In general, the VAR model for k-variables, i.e., each equation was an equation with one of the other variables and a deterministic trend component. A common form, $\operatorname{VAR}(\mathrm{p})$ with endogenous k-variable $\mathrm{y}_{\mathrm{t}}=\left(\mathrm{y}_{1 \mathrm{t}}, \ldots, \mathrm{yet}_{\mathrm{et}}\right)$ can be written, Equation 1.

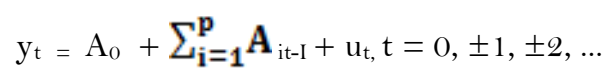


with $\mathrm{A}_{\mathrm{i}, \mathrm{i}}=1, \ldots, \mathrm{p}$ is a dimensional coefficient matrix $(\mathrm{kx} \mathrm{k}), \mathrm{u}_{\mathrm{t}}$ is $\mathrm{k}$-dimensional white-noise with $\mathrm{E}\left(\mathrm{u}_{\mathrm{t}} \mathrm{u}_{\mathrm{t}}\right)^{\prime}=\Sigma \mathrm{u}$ the definitive white-noise. For in-sample, observations could be written in linear form.

$\mathrm{Y}=\mathrm{X} \boldsymbol{\beta}+\boldsymbol{\varepsilon}$, with matrix covariance

$$
\mathbf{Y}=\left[\begin{array}{c}
\mathrm{z} \\
\mathrm{z} \\
\vdots \\
z
\end{array}\right]_{n \times 1} \mathbf{X}=\left[\begin{array}{cccccc}
1 & \mathrm{z}_{(1-1)} & \mathrm{z}_{(1-2)} & \ldots & \mathrm{z}_{(1-p)} \\
1 & \mathrm{z}_{(2-1)} & \mathrm{z}_{(2-2)} & \mathrm{z}_{(2-p)} \\
\vdots & \vdots & \vdots & & \vdots \\
1 & z_{(n-1)} & z_{(n-2)} & \ldots & z_{(n-p)}
\end{array}\right]_{n \times(p+1)} \quad \beta=\left[\begin{array}{c}
\alpha_{0} \\
\varphi_{1} \\
\varphi_{2} \\
\vdots \\
\varphi_{p}
\end{array}\right]_{(p+1) \times 1} \varepsilon=\left[\begin{array}{c}
\varepsilon_{1} \\
\varepsilon_{2} \\
\vdots \\
\varepsilon_{n}
\end{array}\right]
$$

The best order selection criteria used four criteria to select the best order (p) using final prediction error (FPE), Akaike Information Criterion (AIC), Hannan-Quinn Criterion (HQ), Schwarz Information Criterion (SIC). The vector error correction model was used to analyze multivariate time series data that was not stationer. The VAR model that had a linear cointegration relationship would be the VECM model, which could be written, Equation 2.

$$
\Delta \mathrm{y}_{\mathrm{t}}=\alpha \beta^{\mathrm{T}} \mathrm{y}_{\mathrm{t}-1}+\Gamma_{1} \Delta \mathrm{y}_{\mathrm{t}-1}+\ldots+\Gamma_{\mathrm{p}-1} \Delta \mathrm{y}_{\mathrm{t}-\mathrm{p}+1}+\mathrm{U}_{\mathrm{t}} \mathrm{O}, \Gamma_{\mathrm{i}}=-\left(\mathrm{I}-\mathrm{A}_{1}-\ldots \mathrm{A}_{\mathrm{t}}\right)
$$

The $\alpha$ and $\beta$ had dimensions $\mathrm{N}$ x r, where $\mathrm{N}$ was the number of variables, and $\mathrm{r}$ was the cointegration degree. The degree of cointegration indicated some long-term relationship between the changes $\mathrm{y}_{\mathrm{t}}$ of the model we create. Hence, cointegration was the main requirement of using VECM, where the degree of cointegration was determined using the Johansen Test. Short-term and long-term restrictions occurred in VAR and VECM models. Short-term restriction occurred if one variable could not immediately respond to changes or shocks in another variable. While long-term restriction occurred when there was a cointegration or long-term relationship between the variables used.

At the end of modeling, IRF and PEVD would be analyzed and reviewed. The final results, along with the best models, whether stationer or stationer, could be used as a reference in forecasting IPO events. Step in the Johansen test, namely:

Ho: there was $r$, where $r=0.1, \ldots k-1$ cointegration equation, no cointegration or long-term relationship between variables.

H1: there was a cointegration equation, a cointegration, or a long-term relationship between variables.

Trace tests were used, where the test criteria were rejected Ho if the trace test statistical value was more than the critical value of Mackinnon-Hang-Michelis. The authors used Akaike's information criteria for optimum lag (p) selection, better known as the Akaike Information Criterion (AIC). Where the AIC was defined as follows: $\mathrm{AIC}(\mathrm{p})=$ $\operatorname{logdet}\left(\sum \mathrm{u}(\mathrm{p})\right)+\frac{\mathbf{2} \mathbf{P k}^{n} \mathbf{2}}{\mathbf{T}}$, with $\left(\sum \mathrm{u}(\mathrm{p})\right)=\mathrm{T}^{-1} \mathbf{\Sigma}_{\mathbf{t}=\mathbf{1}}^{\mathbf{T}} \hat{\mathrm{U}}_{\mathrm{t}} \hat{\mathrm{U}}_{\mathrm{t}}$, where $\mathrm{T}$ was the sample size, and $\mathrm{k}$ was the number of'endogenous variables. Value of $\mathrm{p}^{*}$ that minimizes the criteria of information in intervals of $1, \mathrm{P}_{\max }$ to be observed or selected.

\section{RESULT}

There were 181 companies listed on the mainboard and development board for 2015-2019 on Indonesia Stock Exchange. The IPO funds rose, amounting to 129.51 trillion rupiahs or equivalent USD 8.93 billion (1usd=IDR 14,500), see Table 1. 
Table-1. Number of IPO Companies, Acquisition Fund and Number of Shares.

\begin{tabular}{c|c|c|c|c|c|c}
\hline Description & $\mathbf{2 0 1 5}$ & $\mathbf{2 0 1 6}$ & $\mathbf{2 0 1 7}$ & $\mathbf{2 0 1 8}$ & $\mathbf{2 0 1 9}$ & Total \\
\hline IPO Funds (Bio IDR) & $7,324.6$ & $11,424.7$ & $34,318.8$ & $61,657.2$ & $14,786.6$ & $129,511.9$ \\
\hline Shares Float (Million) & $23,950.1$ & $24,817.5$ & $9,439.0$ & $168,454.0$ & $39,745.5$ & $266,406.1$ \\
\hline Companies & 17 & 15 & 36 & 58 & 55 & 181 \\
\hline
\end{tabular}

Table-2. Descriptive Statistic.

\begin{tabular}{l|c|c|c|c|c|c}
\hline \multirow{2}{*}{ Description } & $\mathbf{N}$ & Minimum & Maximum & \multicolumn{2}{|c|}{ Mean } & Std. Deviation \\
\cline { 2 - 7 } & Statistic & Statistic & Statistic & Statistic & Std. Error & Statistic \\
\hline 1st Initial Return & 181 & -1.8 & 1.7 & 0.326 & 0.0291 & 0.3910 \\
\hline CAR-5Days & 181 & -0.8 & 2.1 & 0.546 & 0.0417 & 0.5616 \\
\hline CAR-30Days & 181 & -0.8 & 2.6 & 0.385 & 0.0432 & 0.5809 \\
\hline
\end{tabular}

The descriptive statistical test resulted in the values of Initial Return (IR), Cumulative Abnormal Return fivedays (CA5D). Cumulative Abnormal Return thirty-days (CA30D) in Table 2 above showed an average of 0.326 , 0.546 , and 0.385 with maximum data distribution of 2.60. It also showed a minimum of $-1.80,-0.08-0.08$ with standard deviations of 0.0291, 0.0417, and 0.0432 for IR, CA5D, and CA30D. We concluded that for all IPO shares, the average CA5D than IR and CA30D. Hence we claimed that under-pricing performed on the Indonesia stock exchange provided that the lowest minimum value existed in the IR variable. At the same time, the highest limit found in the CA30D due to the Buy \& Hold practices, Sudarmaji, Ambarwati, Hubbansyah, and Shinta (2020).

Based on empirical studies by Sudarmaji et al. (2020) this article revealed that underpricing strategy led to Pump-and-Dump \& Flipping strategy occurred on the Indonesia Stock Exchange. The underpricing strategy could be written in the following ways:

$$
\text { CA30Dit }=\alpha_{1}+\beta_{1} \text { CA5 D } i t+\beta_{2} \text { InflationR }_{\text {it }}+\beta_{3} \text { LnIPOFund }_{i t}+\beta_{4} \ln \text { Price }_{i t}+\beta_{5} \text { lnFloat }_{i t}+\varepsilon_{\text {it }}
$$

Where CA30D represented an abnormal cumulative return of thirties days. CA5D was a cumulative return of five days. Inflation was an inflation rate. LnIPOFund showed the amount of fundraising at IPO. LnPrice was the IPO stock price, and LnFloat showed the total number of shares floating in the IPO; subscript $\mathrm{i}(\mathrm{i}=1, \ldots, \mathrm{N})$ and $\mathrm{t}$ $(\mathrm{t}=1, \ldots, \mathrm{T})$ indicated, respectively, individual IPO shares and periods. The lower IPO prices, lower IPO fundraising, a small number of floating IPO stocks traded, and an increase in inflation were expected to increase five days' cumulative return. In the end, it prompted an abnormal cumulative thirty days. On the other hand, the higher IPO prices, the large number of floating IPO shares traded, and the high inflation rate were expected to decrease to an abnormal cumulative return rate in the next thirty days.

\subsection{Unit Roots Test}

The most common and widely used test for stationary data tests was the Dickey-Fuller Augmented test criteria (ADF test). This test had the following equations presented.

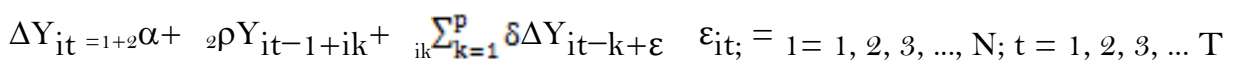

Where: $\Delta \mathrm{Y}_{\mathrm{t}}$ was the first difference from $\mathrm{Y} ;=\alpha_{1}$, as a constant value or intercept. $\rho_{2}$ was the regression coefficient for trends; was the regression coefficient for Y lag; was a regression coefficient for Y lag differences; lagdifference; $\varepsilon$ was a term of error; $p$ was lag, and t was the time. 
Table-3. Individual Unit-Root analysis of InflationR, LnPrice, LnIPOFund and LnFloat

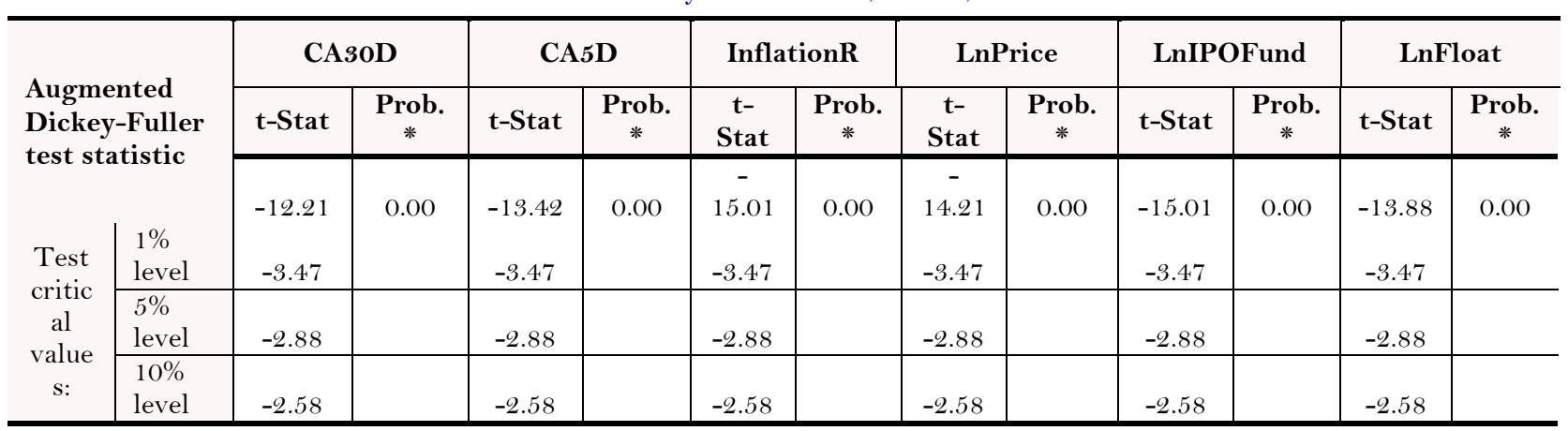

The test results of Table 3 above showed that overall, the CA30D and CA5D variables show stationary in the level value. Meanwhile, inflation, LnIPOFund, LnPrice, and lnFloat showed stationary in the first difference, with statistical test scores smaller than critical scores on the ADF of 0.01. Based on autoregressive reverse root data and characteristic polynomial roots, the authors concluded that the VECM model formed in a stable state since all the roots were inside the circle unit see Figure 2.

\section{Inverse Roots of AR Characteristic Polynomial}

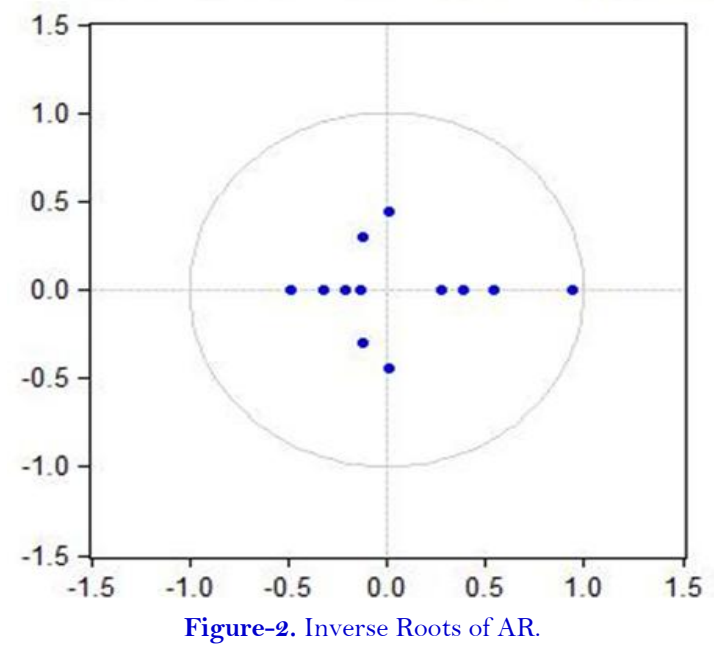

\subsection{Optimal Lag Selection}

The optimal lag length was two based on Akaike Information Criterion (AIC) and Schwarz Bayesian Criterion (SBC). Table 4.

Table-4. VAR Lag Order Selection for InflationR, LnPrice, LnIPOF und and LnFloat

\begin{tabular}{c|c|c|c|c|c|c}
\hline Lag & LogL & LR & FPE & AIC & SC & HQ \\
\hline 1 & 409.361 & NA & 0.000 & -4.316 & $-3.660139^{*}$ & $-4.050109^{*}$ \\
\hline 2 & 448.134 & $72.16641^{*}$ & $5.22 \mathrm{e}-10^{*}$ & $-4.348369^{*}$ & -3.036 & -3.816 \\
\hline 3 & 469.084 & 37.541 & 0.000 & -4.174 & -2.206 & -3.376 \\
\hline 4 & 491.691 & 38.942 & 0.000 & -4.020 & -1395 & -2.955 \\
\hline 5 & 511.561 & 32.848 & 0.000 & -3.833 & -0.552 & -2.502 \\
\hline 6 & 527.157 & 24.702 & 0.000 & -3.597 & 0.340 & -2.000 \\
\hline 7 & 551.994 & 37.613 & 0.000 & -3.468 & 1.125 & -1.605 \\
\hline 8 & 571.371 & 28.002 & 0.000 & -3.276 & 1.973 & -1.146 \\
\hline
\end{tabular}




\subsection{Johansen Cointegration Test}

The integration analysis findings used Johansen's maximum likelihood method using maximum eigenvalue and trace statistics were listed in Table 5. Both produce evidence to refute the null hypothesis that vectors for vector integration at an actual 5 percent rate.

Table-5. Cointegration Test.

\begin{tabular}{|c|c|c|c|c|}
\hline \multicolumn{4}{|c|}{ Unrestricted Cointegration Rank Test (Trace) } & \\
\hline Hypothesized & & Trace & 0,05 & \\
\hline No. of CE(s) & Eigenvalue & Statistic & Critical Value & Prob.** \\
\hline None ${ }^{*}$ & 0.358515 & 268.4658 & 95.75366 & 0.00 \\
\hline At most $1 *$ & 0.313162 & 189.4393 & 69.81889 & 0.00 \\
\hline At most $2^{*}$ & 0.226732 & 122.5724 & 47.85613 & 0.00 \\
\hline At most $3^{*}$ & 0.208252 & 76.80324 & 29.79707 & 0.00 \\
\hline At most $4^{*}$ & 0.15403 & 35.23798 & 15.49471 & 0.00 \\
\hline At most $5^{*}$ & 0.030228 & 5.463616 & 3.841466 & 0.02 \\
\hline \multicolumn{5}{|c|}{ * denotes rejection of the hypothesis at the 0.05 level } \\
\hline \multicolumn{5}{|c|}{ ***MacKinnon-Haug-Michelis (1999) p-values } \\
\hline Hypothesized & & Max-Eigen & 0,05 & \\
\hline No. of $\mathrm{CE}(\mathrm{s})$ & Eigenvalue & Statistic & Critical Value & Prob.*** \\
\hline None * & 0.358515 & 79.02651 & 40.07757 & 0.00 \\
\hline At most $1^{*}$ & 0.313162 & 66.86693 & 33.87687 & 0.00 \\
\hline At most $2^{*}$ & 0.226732 & 45.76917 & 27.58434 & 0.00 \\
\hline At most $3 *$ & 0.208252 & 41.56526 & 21.13162 & 0.00 \\
\hline At most $4^{*}$ & 0.15403 & 29.77436 & 14.2646 & 0.00 \\
\hline At most $5^{*}$ & 0.030228 & 5.463616 & 3.841466 & 0.02 \\
\hline
\end{tabular}

\subsection{Vector Error Correction Model}

Based on these results, the short-term relationship existed between CA50D and IPO prices, lower IPO funds, and the floating number of IPOs in terms of Pump-and-Dump \& Flipping Strategies on the Indonesia Stock Exchange in 2015-2019, see Table 6

Table-6. The short-run causality from VECM estimates result.

\begin{tabular}{c|c|c|c|c}
\hline CA5D(-1) & InflationR(-1) & LnFloat(-1) & LnIPOFund(-1) & LnPrice(-1) \\
\hline$-0,011$ & 56.194 & 0.447 & -0.585 & 1.774 \\
\hline$-0,266$ & -35.789 & -0.223 & -0.187 & -0.241 \\
\hline$[-0.04014]$ & {$[1.57017]$} & {$[2.00574]$} & {$[-3.12333]$} & {$[7.34775]$} \\
\hline
\end{tabular}

Variable LnFloat and LnPrice influenced positively on Pump-and-Dump \& Flipping Strategy (CA30D). It meant that a change in the stock (float) and the price change would cause the pump-and-dump \& flipping strategy to occur by 0.447 percent and 1,774 percent. Meanwhile, on the variable amount of funds to be raised in an IPO or IPOFund negative influenced on the Pump-and-Dump \& Flipping Strategy (CA30D), in other words, a null hypothesis was accepted. It meant that if there were a change in the amount of money to be raised (LnIPOFund) would cause the possibility of the Pump-and-Dump \& Flipping Strategy to drop by -0.585 percent. The exact process was repeated in other models to test the short-term causality between past slowdowns in inflation (inflation) and rising share prices in five trading days (CA5D). For variable inflation (inflation) and share price increased within five trading days (CA5D), there was no short-term link to the Pump-and-Dump \& Flipping (CA30D) Strategy. Statistically, (inflation) and the increase in the share price in CA5D had a probability value of Chi-square, which was $<0.05$; thus, the null hypothesis was accepted. It meant that there was no short-term 
causality between (inflation) and the increase in the share price in five trading days (CA5D) and the Pump-andDump \& Flipping Strategy (CA30D).

In Table 7 , the results of estimates of six models showed three models had long-term causality, namely the floating number (LnFloat), Cumulative abnormal five days (CA5D), and the IPO price (LnPrice). Meanwhile, three modes did not have long-term causality, namely LnIPOFund, inflation, and CA30D. There was one model in CA5D that had long-term causality in 5\% significant long-term causality. Statistically, the first model showed that the ECT coefficient was -0.097, which meant the long-term balanced relationship was valid between the stock's variable IPO floating number (LnFloat) and the CA30D. It implied that -9.70 that imbalance of the previous period shocks reunited a long-term balance in the current period negative for Lnfloat. In other words, there were long-term causality variable IPO floating numbers LnFloat, LnPrice, LnIPOFund, inflation, CA5D, and CA30D. In the second model, there was a negative effect on the previous year's Variable IPO floating number (LnFloat), which showed the coefficient value of -0.905 . It meant that the $1 \%$ increase in LnFloat reduced CA30D by $90.50 \%$. These findings suggested that an increase in LnFloat would negatively impact CA30D in Indonesia.

Likewise, the third model in the floating number (LnFloat), which has an ECT coefficient of 0.432, meant that there was the validity of the long-term equilibrium relationship between LnFloat and CA30D; this implied that the $43.2 \%$ imbalance of the previous period shocks reunited into a long-term balance in the current period positively. In other words, there was long-term causality of LnPrice, LnFloat, LnIPOFund, inflation, CA5D, and CA30D. However, LnFloat-2 and LnPrice-1 indicated that they had a significant effect on the CA3OD.

Table-7. The short-run causality from VECM estimates result.

\begin{tabular}{|c|c|c|c|c|c|c|}
\hline $\begin{array}{l}\text { Error } \\
\text { Correction: }\end{array}$ & $\mathrm{D}(\mathrm{CA30D})$ & D(CA5D) & $\mathbf{D}$ (InflationR) & D(LnFloat) & D(LnIPOFund) & D(LnPrice) \\
\hline \multirow[t]{3}{*}{ CointEq1 } & -0.120 & -0.097 & 0.000 & 0.432 & -0.294 & -0.905 \\
\hline & -0.078 & -0.059 & 0.000 & -0.140 & -0.186 & -0.117 \\
\hline & {$[-1.55279]$} & {$[-1.65867]$} & {$[-1.43697]$} & {$[3.07581]$} & {$[-1.57851]$} & {$[-7.72162]$} \\
\hline \multirow[t]{3}{*}{$\mathrm{D}(\mathrm{CA} 30 \mathrm{D}(-1))$} & -0.859 & $-0,009$ & 0.000 & 0.133 & 1.501 & 0.875 \\
\hline & -0.446 & $-0,337$ & -0.001 & -0.808 & -1.073 & -0.675 \\
\hline & {$[-1.92436]$} & {$[-0.02770]$} & [-0.05949] & {$[0.16465]$} & [ 1.39895$]$ & {$[1.29712]$} \\
\hline \multirow[t]{3}{*}{$\mathrm{D}(\mathrm{CA} 30 \mathrm{D}(-2))$} & 0.042 & 0.297 & 0.000 & 0.015 & 0.775 & 0.370 \\
\hline & -0.444 & -0.335 & -0.001 & -0.803 & -1.066 & $-0,671$ \\
\hline & {$[0.09387]$} & {$[0.88619]$} & {$[0.16843]$} & {$[0.01870]$} & {$[0.72707]$} & {$[0.55196]$} \\
\hline \multirow[t]{3}{*}{$\mathrm{D}(\mathrm{CA} 5 \mathrm{D}(-1))$} & 0.512 & -0.439 & 0.000 & -0.570 & -1.620 & -0.328 \\
\hline & -0.585 & -0.442 & -0.001 & -1.060 & -1.407 & -0.885 \\
\hline & {$[0.87489]$} & {$[-0.99175]$} & {$[0.32261]$} & {$[-0.53772]$} & {$[-1.15192]$} & {$[-0.37029]$} \\
\hline \multirow[t]{3}{*}{$\mathrm{D}(\mathrm{CA} 5 \mathrm{D}(-2))$} & -0.552 & -0.751 & 0.000 & -0.169 & -0.803 & -0.229 \\
\hline & -0.588 & -0.445 & -0.001 & -1.066 & -1.414 & -0.890 \\
\hline & {$[-0.93742]$} & {$[-1.68896]$} & {$[0.23076]$} & {$[-0.15836]$} & {$[-0.56759]$} & {$[-0.25722]$} \\
\hline \multirow{3}{*}{$\begin{array}{l}\mathrm{D}(\text { InflationR }(- \\
1))\end{array}$} & -36.676 & -29.238 & -0.107 & 125.889 & 10.348 & -110.921 \\
\hline & -64.850 & -49.037 & -0.076 & -117.464 & -155.909 & -98.055 \\
\hline & {$[-0.56556]$} & {$[-0.59624]$} & {$[-1.39705]$} & {$[1.07172]$} & {$[0.06637]$} & {$[-1.13121]$} \\
\hline \multirow{3}{*}{$\begin{array}{l}\mathrm{D}(\text { InflationR }(- \\
\text { 2)) }\end{array}$} & -66.233 & -58.043 & -0.018 & 115.326 & 79.351 & -48.277 \\
\hline & -65.230 & -49.325 & -0.077 & -118.154 & -156.824 & -98.630 \\
\hline & {$[-1.01538]$} & {$[-1.17676]$} & {$[-0.23984]$} & {$[0.97607]$} & {$[0.50599]$} & {$[-0.48948]$} \\
\hline $\mathrm{D}(\operatorname{LnFloat}(-1))$ & 0.059 & 0.036 & 0.000 & -0.902 & -0.051 & 0.131 \\
\hline
\end{tabular}




\begin{tabular}{|c|c|c|c|c|c|c|}
\hline $\begin{array}{l}\text { Error } \\
\text { Correction: }\end{array}$ & D(CA30D) & D(CA5D) & D(InflationR) & D(LnFloat) & D(LnIPOFund) & $\mathrm{D}($ LnPrice $)$ \\
\hline & -0.084 & -0.064 & 0.000 & -0.153 & -0.203 & -0.128 \\
\hline & [0.69979] & {$[0.56741]$} & {$[1.29681]$} & {$[-5.90183]$} & {$[-0.25036]$} & {$[1.03013]$} \\
\hline \multirow[t]{3}{*}{$\mathrm{D}($ LnFloat $(-2))$} & -0.153 & -0.118 & 0.000 & -0.435 & -0.156 & 0.079 \\
\hline & -0.082 & -0.062 & 0.000 & -0.149 & -0.197 & -0.124 \\
\hline & {$[-1.85919]$} & {$[-1.90252]$} & {$[1.40073]$} & {$[-2.92939]$} & {$[-0.79260]$} & {$[0.63745]$} \\
\hline \multirow{3}{*}{$\begin{array}{l}\text { D(LnIPOFund(- } \\
1))\end{array}$} & -0.086 & -0.055 & 0.000 & 0.219 & -0.555 & -0.125 \\
\hline & -0.079 & -0.059 & 0.000 & -0.142 & -0.189 & -0.119 \\
\hline & {$[-1.08913]$} & {$[-0.91723]$} & {$[-1.34373]$} & {$[1.53508]$} & {$[-2.93334]$} & {$[-1.05371]$} \\
\hline \multirow{3}{*}{$\begin{array}{l}\text { D } \\
\text { (LnIPOF und(- } \\
2) \text { ) }\end{array}$} & 0.069 & 0.058 & 0.000 & 0.059 & -0.203 & -0.045 \\
\hline & -0.074 & -0.056 & 0.000 & -0.134 & -0.178 & -0.112 \\
\hline & {$[0.93572]$} & {$[1.04327]$} & {$[-1.45927]$} & {$[0.43907]$} & {$[-1.14363]$} & [-0.40698] \\
\hline \multirow[t]{3}{*}{$\mathrm{D}($ LnPrice $(-1))$} & 0.219 & 0.167 & 0.000 & -0.617 & 0.091 & 0.201 \\
\hline & -0.122 & -0.092 & 0.000 & -0.220 & -0.292 & -0.184 \\
\hline & {$[1.80026]$} & {$[1.81160]$} & {$[1.23710]$} & {$[-2.79971]$} & {$[0.31117]$} & {$[1.09538]$} \\
\hline \multirow[t]{3}{*}{$\mathrm{D}($ LnPrice $(-2))$} & -0.049 & -0.038 & 0.000 & -0.252 & -0.009 & 0.111 \\
\hline & -0.091 & -0.069 & 0.000 & -0.165 & -0.219 & -0.138 \\
\hline & {$[-0.53580]$} & {$[-0.54924]$} & {$[1.13267]$} & {$[-1.52735]$} & {$[-0.04237]$} & {$[0.80159]$} \\
\hline \multirow[t]{3}{*}{$\mathrm{C}$} & 0.001 & -0.001 & 0.000 & 0.000 & -0.010 & -0.011 \\
\hline & -0.047 & -0.036 & 0.000 & -0.086 & -0.114 & -0.071 \\
\hline & {$[0.01650]$} & {$[-0.01474]$} & {$[0.04731]$} & {$[0.00542]$} & {$[-0.09223]$} & {$[-0.15659]$} \\
\hline R-squared & 0.411 & 0.389 & 0.066 & 0.411 & 0.342 & 0.539 \\
\hline Adj. R-squared & $0, .64$ & 0.341 & -0.008 & 0.364 & 0.290 & 0.502 \\
\hline
\end{tabular}

However, LnFloat-2 and LnPrice-1 indicated that it has a significant effect on the CA30D. The third model estimated results in CA5D show a long-term balance between LnPrice, LnFloat, LnIPOFund, inflation, CA30D and CA5D at a significant 5\% rate. However, in part, only LnFloat-2 and LnPrice-1 showed an insignificant effect on the CA30D. On the other hand, the fourth, fifth, and sixth models showed no long-term causality of variable LnFloat, LnPrice, LnIPOFund, inflation, CA5D, and CA30D. Statistically, variable LnFloat, LnPrice, LnIPOFund, inflation, CA5D did not affect CA30D.

\subsection{Innovative Accounting Approach}

\subsubsection{Impulse-Response Function}

Based on Figure 3 below, the CA30D responded to the CA5D variable shock, inflation, LnFloat, and LnPrice began to surprise with opposing trends, including variables in the LNIPOFund variable. Long-term dynamics response on LnFloat, LnIPOFund, and LnPrice occurred in the 2nd period. Variance decomposition described how many variance errors were predicted from certain effect variables described by innovations resulting from other effect variables in the system for some time.

\subsubsection{Variance Decomposition}

Variance decomposition described the variance proportion of errors from different impact factors of CO30D on the Indonesia Stock Exchange. It described the relative effect that could explain each variable's contribution to the system variable. Variance decomposition results were presented in Table 8. For CA30D, the LNPrice variable shock 
was the most significant factor in explaining its variability. Most variables had a surprising account in the third period. Subsequently, we would highlight the most critical shocks that can change each effect that was decomposed. The empirical evidence indicated that $93.68 \%$ of CA30D was due to its innovative shocks. The variable CA5D was mainly affected by CA5D, and the variable LnPrice was $91.866 \%$ and $2.896 \%$, respectively. At the same time, 2.461 $\%$ was $\mathrm{CA} 5 \mathrm{D}$ due to its innovator shocks with a standard error of $0.851 \%$. Variable inflation component was mainly affected variable inflation by $84.874 \%$ by its shocks. $94.874 \%$ of the inflation rate was explained by one standard deviation shock in its innovative shocks. Variable inflation component was mainly affected variable inflation by $84.874 \%$ by its shocks. Likewise, the Variable Lnfloat component was mainly affected by its Lnfloat by $82.20 \%$ and the CA5D by $26.43 \%$. The variable LnIPOFund component was mainly affected by its LnIPOFund by $49.00 \%$ and by the LnFloat by $40.09 \%$. The variable LnPrice component was mainly affected by its LnPrice by $19.80 \%$, by the CA30D and LnIPOFund by $44.80 \%$ and $30.76 \%$, respectively.
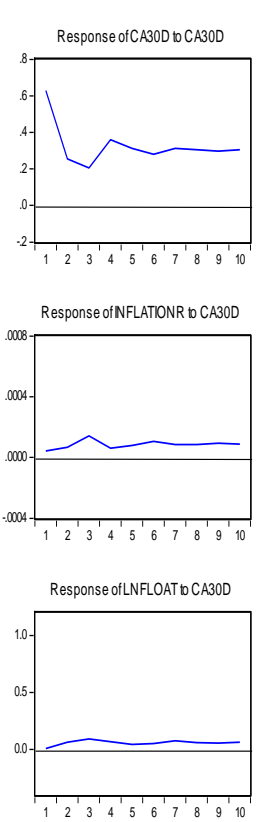

Response ofLNPRICE to CA3OD

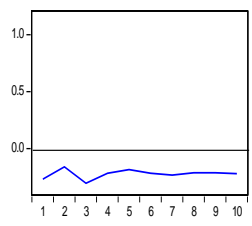

Response ofLNIPOFUND to CA3OD

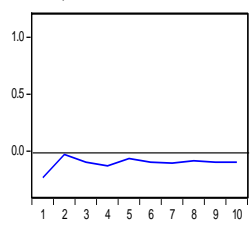

Response ofCA5D to CA3OD

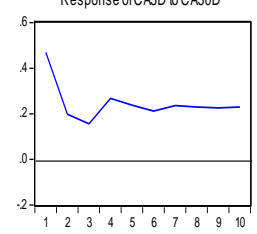

Response to Cholesky One S.D. Innovations
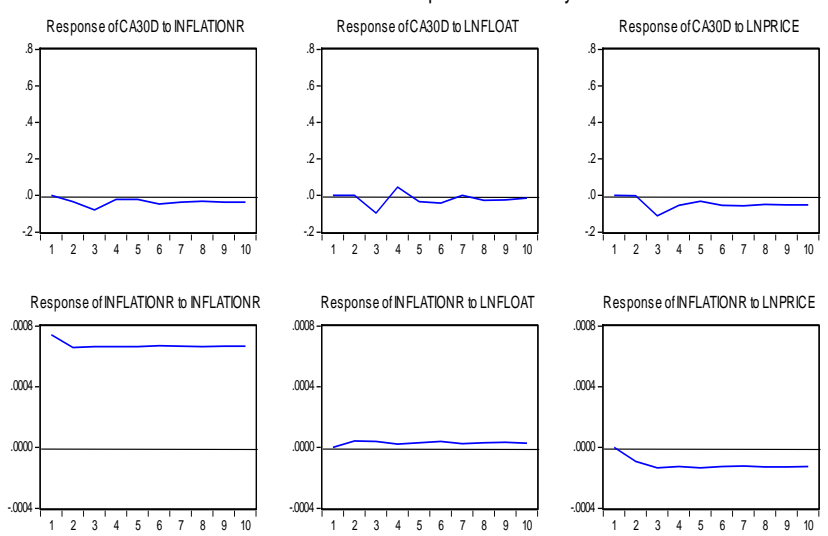

Response ofLNFLOAT TO NFLATIONA

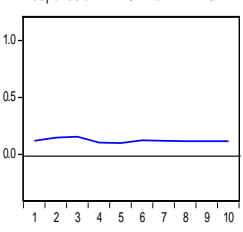

Response ofLNPRICE to NFLATIONA

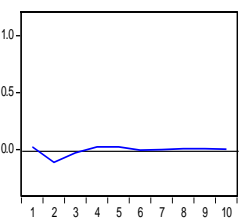

Response ofLNPOFUND to NFLATIONR

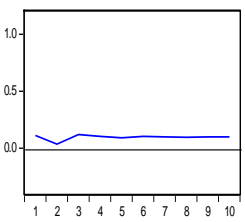

Response ofCA5D to INFLATIONR

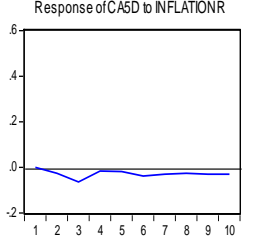

Response of INFLATIONR t LNFLOAT
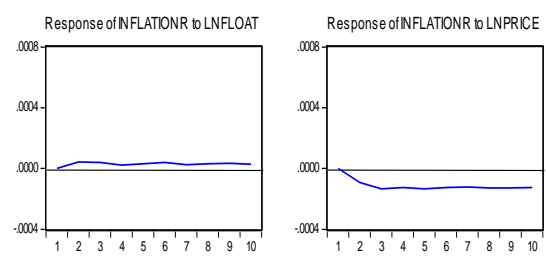

Response ofLNFLOAT to LNFLOAT

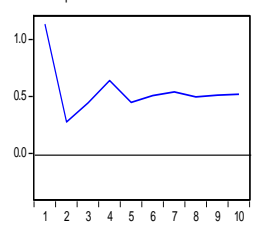

Response ofLNPRICEE to LNFLAT

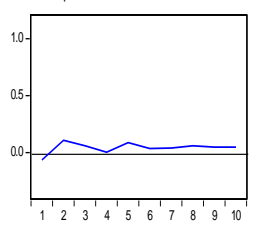

Response ofLNPOFUND to LNFLOAT

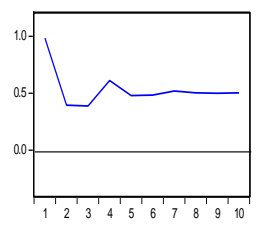

Response ofCA5D to LNFLOAT
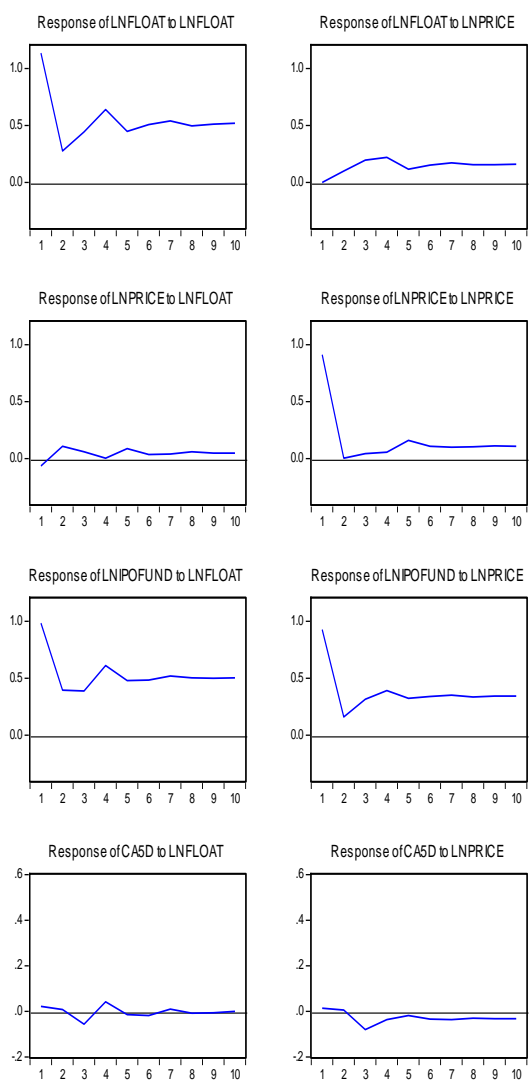

Response ofLNPRICEto LNPRICE

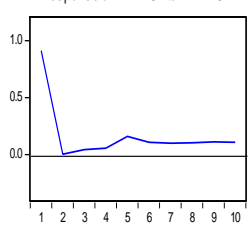

Response ofLNPOFUND to LNPRICE

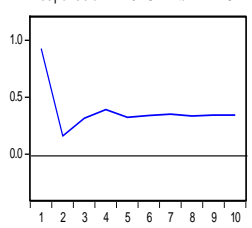

Response ofCA5D to LNPRICE

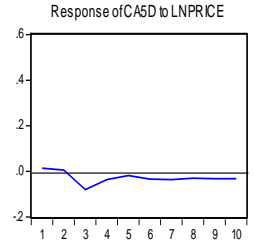

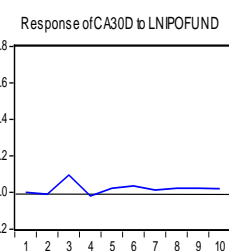
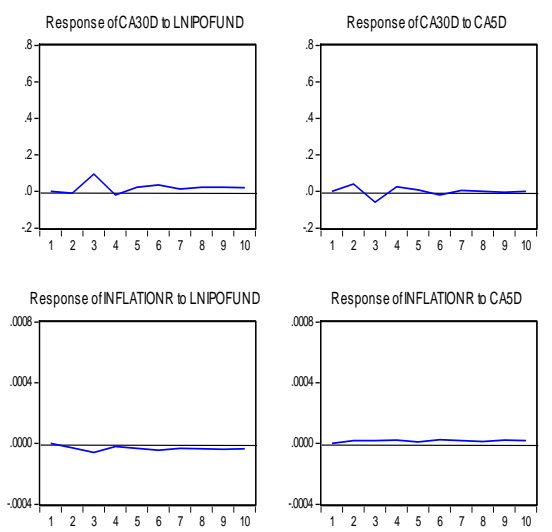

Response ofLNFLOAT T LNPOFUND
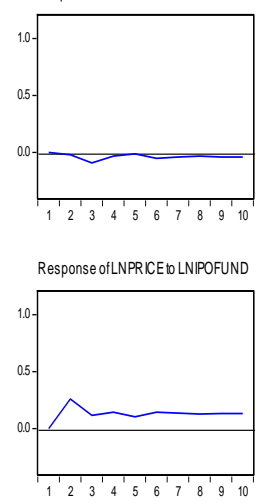

Response ofLNPOFUND to LNPOFUND

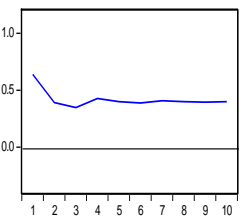

Response ofCA5D to LNPOFUND

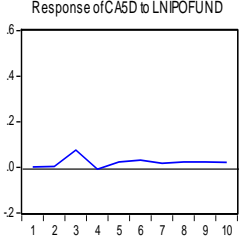

Response ofLNPRICE to LNPOFUND
Response ofNFLATONR TO CASD

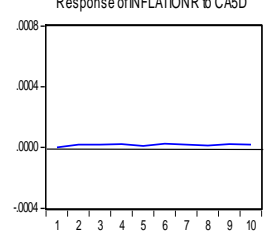

Response ofLNFLOAT to CA5D

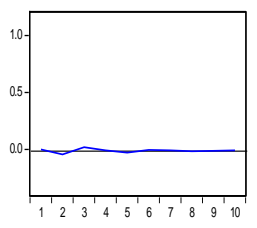

Response ofLNPRICEto CA5D

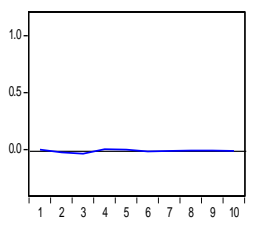

Response ofLNPOFUND to CA5D

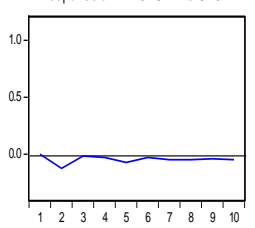

Response of CA5D to CA5D

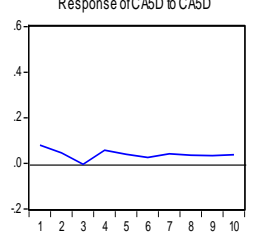

Figure-3. Impulse Responses Variables due to Shocks 
Table-8. CA30D Variance Decomposition.

\begin{tabular}{|c|c|c|c|c|c|c|c|}
\hline \multicolumn{4}{|c|}{ Variance Decomposition of CA30D: } & \multirow[b]{2}{*}{ InflationR } & \multirow[b]{2}{*}{ LnFloat } & \multirow[b]{2}{*}{ LnIPOFund } & \multirow[b]{2}{*}{ LnPrice } \\
\hline Period & S.E. & CA30D & CA5D & & & & \\
\hline 1 & 0.630 & 100.000 & 0.000 & 0.000 & 0.000 & 0.000 & 0.000 \\
\hline 2 & 0.681 & 99.395 & 0.314 & 0.237 & 0.016 & 0.036 & 0.002 \\
\hline 3 & 0.739 & 92.174 & 1.978 & 1.323 & 0.989 & 0.160 & 3.376 \\
\hline 4 & 0.826 & 92.817 & 1.680 & 1.121 & 1.021 & 0.619 & 2.743 \\
\hline 5 & 0.885 & 93.331 & 1.466 & 1.034 & 1.038 & 0.566 & 2.564 \\
\hline 6 & 0.933 & 93.027 & 1.470 & 1.182 & 1.061 & 0.554 & 2.705 \\
\hline 7 & 0.986 & 93.280 & 1.315 & 1.196 & 0.949 & 0.645 & 2.615 \\
\hline 8 & 1.035 & 93.453 & 1.213 & 1.181 & 0.916 & 0.647 & 2.589 \\
\hline 9 & 1.079 & 93.534 & 1.145 & 1.205 & 0.879 & 0.656 & 2.581 \\
\hline 10 & 1.124 & 93.677 & 1.064 & 1.214 & 0.822 & 0.675 & 2.548 \\
\hline \multicolumn{8}{|c|}{ Variance Decomposition of CA5D: } \\
\hline 1 & 0.476 & 97.009 & 2.991 & 0.000 & 0.000 & 0.000 & 0.000 \\
\hline 2 & 0.518 & 96.457 & 3.268 & 0.260 & 0.010 & 0.001 & 0.004 \\
\hline 3 & 0.558 & 90.658 & 3.106 & 1.605 & 0.843 & 0.155 & 3.633 \\
\hline 4 & 0.624 & 90.807 & 3.401 & 1.354 & 0.862 & 0.595 & 2.982 \\
\hline 5 & 0.670 & 91.376 & 3.158 & 1.258 & 0.864 & 0.529 & 2.814 \\
\hline 6 & 0.706 & 91.302 & 2.885 & 1.428 & 0.886 & 0.517 & 2.983 \\
\hline 7 & 0.747 & 91.454 & 2.800 & 1.445 & 0.791 & 0.589 & 2.922 \\
\hline 8 & 0.784 & 91.647 & 2.665 & 1.432 & 0.759 & 0.587 & 2.910 \\
\hline 9 & 0.817 & 91.766 & 2.539 & 1.459 & 0.729 & 0.591 & 2.917 \\
\hline 10 & 0.851 & 91.887 & 2.461 & 1.470 & 0.682 & 0.603 & 2.897 \\
\hline \multicolumn{8}{|c|}{ Variance Decomposition of InflationR: } \\
\hline 1 & 0.001 & 0.331 & 0.000 & 99.668 & 0.000 & 0.000 & 0.000 \\
\hline 2 & 0.001 & 0.631 & 0.012 & 98.237 & 0.156 & 0.882 & 0.082 \\
\hline 3 & 0.001 & 1.782 & 0.009 & 95.857 & 0.212 & 2.034 & 0.107 \\
\hline 4 & 0.001 & 1.550 & 0.008 & 95.753 & 0.183 & 2.260 & 0.246 \\
\hline 5 & 0.002 & 1.509 & 0.009 & 95.466 & 0.192 & 2.522 & 0.302 \\
\hline 6 & 0.002 & 1.647 & 0.011 & 95.151 & 0.211 & 2.686 & 0.294 \\
\hline 7 & 0.002 & 1.625 & 0.010 & 95.109 & 0.200 & 2.746 & 0.309 \\
\hline 8 & 0.002 & 1.618 & 0.009 & 95.017 & 0.202 & 2.828 & 0.326 \\
\hline 9 & 0.002 & 1.638 & 0.009 & 94.918 & 0.207 & 2.897 & 0.331 \\
\hline 10 & 0.002 & 1.638 & 0.008 & 94.874 & 0.204 & 2.938 & 0.338 \\
\hline \multicolumn{8}{|c|}{ Variance Decomposition of LnFloat: } \\
\hline 1 & 1.141 & 0.002 & 6.510 & 1.052 & 92.435 & 0.000 & 0.000 \\
\hline 2 & 1.189 & 0.275 & 6.121 & 2.448 & 90.365 & 0.369 & 0.421 \\
\hline 3 & 1.300 & 0.720 & 6.657 & 3.481 & 85.835 & 0.912 & 2.395 \\
\hline 4 & 1.470 & 0.773 & 6.825 & 3.188 & 84.407 & 1.862 & 2.944 \\
\hline 5 & 1.544 & 0.776 & 6.638 & 3.292 & 84.366 & 2.011 & 2.917 \\
\hline 6 & 1.638 & 0.784 & 6.712 & 3.481 & 83.699 & 2.097 & 3.226 \\
\hline 7 & 1.738 & 0.868 & 6.760 & 3.560 & 83.079 & 2.305 & 3.428 \\
\hline 8 & 1.818 & 0.889 & 6.731 & 3.637 & 82.740 & 2.449 & 3.554 \\
\hline 9 & 1.899 & 0.895 & 6.735 & 3.693 & 82.471 & 2.538 & 3.667 \\
\hline 10 & 1.979 & 0.921 & 6.746 & 3.742 & 82.202 & 2.625 & 3.764 \\
\hline \multicolumn{8}{|c|}{ Variance Decomposition of LnIPOFund: } \\
\hline 1 & 1.514 & 2.381 & 7.495 & 0.526 & 35.777 & 53.821 & 0.000 \\
\hline 2 & 1.626 & 2.095 & 6.508 & 0.498 & 37.197 & 51.833 & 1.870 \\
\hline 3 & 1.742 & 2.129 & 6.313 & 0.892 & 36.751 & 51.926 & 1.989 \\
\hline 4 & 1.941 & 2.170 & 6.157 & 0.997 & 38.434 & 50,206 & 2.037 \\
\hline 5 & 2.068 & 2.010 & 5.720 & 1.070 & 38.934 & 50.024 & 2.243 \\
\hline 6 & 2.189 & 1.993 & 5.630 & 1.177 & 39.075 & 49.804 & 2.321 \\
\hline 7 & 2.317 & 1.983 & 5.443 & 1.225 & 39.464 & 49.496 & 2.390 \\
\hline 8 & 2.431 & 1.925 & 5.295 & 1.269 & 39.766 & 49.279 & 2.466 \\
\hline 9 & 2.539 & 1.907 & 5.205 & 1.318 & 39.918 & 49.138 & 2.514 \\
\hline 10 & 2.645 & 1.889 & 5.101 & 1.350 & 40.099 & 49.001 & 2.560 \\
\hline \multicolumn{8}{|c|}{ Variance Decomposition of LnPrice: } \\
\hline 1 & 0.952 & 7.993 & 1.866 & 0.045 & 1.175 & 59.596 & 29.325 \\
\hline 2 & 1.012 & 9.635 & 1.659 & 1.345 & 2.175 & 54.983 & 30.203 \\
\hline
\end{tabular}




\begin{tabular}{c|l|l|l|l|l|l|l}
\hline 3 & 1.068 & 16.937 & 1.506 & 1.284 & 2.321 & 50.404 & 27.549 \\
\hline 4 & 1.101 & 19.864 & 1.432 & 1.252 & 2.184 & 48.730 & 26.538 \\
\hline 5 & 1.136 & 21.376 & 1.515 & 1.216 & 2.515 & 48.439 & 24.939 \\
\hline 6 & 1.170 & 23.577 & 1.438 & 1.148 & 2.451 & 47.679 & 23.707 \\
\hline 7 & 1.205 & 26.006 & 1.371 & 1.083 & 2.397 & 46.610 & 22.533 \\
\hline 8 & 1.236 & 27.670 & 1.343 & 1.031 & 2.466 & 45.935 & 21.554 \\
\hline 9 & 1.267 & 29.232 & 1.307 & 0.982 & 2.453 & 45.387 & 20.639 \\
\hline 10 & 1.298 & 30.765 & 1.267 & 0.936 & 2.436 & 44.798 & 19.798 \\
\hline
\end{tabular}

\section{CONCLUSIONS}

The paper investigated long-term causality between LnFloat, LnPrice, LnIPOFund, inflation, CA5D, and CA30D using VECM-based Granger causality models from 2015-2019. Empirical results showed long-term and short-term causality between variables at significance rates of $1 \%, 5 \%$, and $10 \%$ in Indonesia. The main results for the granger's presence and causality direction were LnFloat, and LnPrice had causal evidence in long-term or short-term causality with Cumulative Abnormal Return thirty days (CAR30D). However, the LnIPOFund had evidence of cause in short-term causality alone. On the other hand, there was no evidence of a cause of variable Inflation and CA5D for long-term causality and short-term causality with Cumulative Abnormal Return thirty days (CAR30D).

Funding: This study received no specific financial support.

Competing Interests: The authors declare that they have no competing interests.

Acknowledgement: All authors contributed equally to the conception and design of the study.

\section{REFERENCES}

Ang, A., Hodrick, R. J., Xing, Y., \& Zhang, X. (2006). The cross-section of volatility and expected returns. The Journal of Finance, 61(1), 259-299.

Arena, M. P., Haggard, K. S., \& Yan, X. (2008). Price momentum and idiosyncratic volatility. Financial Review, 43(2), 159-190. Available at: https://doi.org/10.1111/j.1540-6288.2008.00190.x.

Bairagi, R. K., \& Dimovski, W. (2011). The underpricing of US REIT IPOs: 1996-2010. Journal of Property Research, 28(3), 233248. Available at: https://doi.org/10.1080/09599916.2011.577905.

Bansal, R., \& Khanna, A. (2012). Post Indian stock market's crisis and its impact on IPOs underpricing: Evidence from 20082011. Asian Journal of Management Research, 3(1), 01-11.

Bayley, L., Lee, P. J., \& Walter, T. S. (2006). IPO flipping in Australia: cross-sectional explanations. Pacific-Basin Finance Journal, 14(4), 327-348. Available at: https://doi.org/10.1016/j.pacfin.2006.01.002.

Beaulieu, M., \& Bouden, H. M. (2020). Does idiosyncratic risk matter in IPO long-run performance? Review of Quantitative Finance and Accounting, 55(3), 935-981. Available at: https://doi.org/10.1007/s11156-019-00864-x.

Campbell, J. Y., \& Taksler, G. B. (2003). Equity volatility and corporate bond yields. The Journal of Finance, 58(6), $2321-2350$. Available at: https://doi.org/10.1046/j.1540-6261.2003.00607.x.

Chang, E., Chen, C., Chi, J., \& Young, M. (2008). IPO underpricing in China: New evidence from the primary and secondary markets. Emerging Markets Review, 9(1), 1-16. Available at: https://doi.org/10.1016/j.ememar.2007.06.002.

Chen, A., \& Kao, L. (2006). The benefit of excluding institutional investors from fixed-price IPOs: Evidence from Taiwan. Emerging Markets Finance and Trade, 42(6), 5-24. Available at: https://doi.org/10.2753/ree1540-496x420601.

Chen, H.-C., \& Lu, C. (2006). How much do REITs pay for their IPOs? The Journal of Real Estate Finance and Economics, 33(2), 105-125. Available at: https://doi.org/10.1007/s $11146-006-8944-3$.

Deb, \& Mishra. (2009). Long-term risk-adjusted performance of Indian IPOs. International Finance Seminar at IIM. Retrieved from: https://nts2.ximb.ac.in.

Dickey, D. A., \& Fuller, W. A. (1979). Distribution of the estimators for autoregressive time series with a unit root. Journal of the American Statistical Association, 74(366), 427-431. Available at: https://doi.org/10.2307/2286348. 
Dimovski, W. (2010). The underpricing of A-REIT IPOs in Australia during 2002 to 2008. Pacific Rim Property Research Journal, 16(1), 39-51. Available at: https://doi.org/10.1080/14445921.2010.11104294.

Fu, F. (2009). Idiosyncratic risk and the cross-section of expected stock returns. Journal Financ Econ, 91(1), 24-37. Available at: https://doi.org/10.2139/ssrn.2319562.

Indriani, S., \& Marlia, S. (2013). The evidence of IPO underpricing in Indonesia 2009-2013. Review of Integrative Business and Economics Research, 4(1), 299-316.

Islam, M. A., Ali, R., \& Ahmad, Z. (2010). Underpricing of IPOs: the case of Bangladesh. Global Economy and Finance Journal, $3(1), 44-61$.

Johansen, S. (1988). Statistical analysis of cointegration vectors. Journal of Economic Dynamics and Control, 12(2-3), 23 1-254. Available at: https://doi.org/10.1016/0165-1889(88)90041-3.

Manurung, A. H., Juwono, E., \& Siswanti, I. (2019). Behavior of initial return in Indonesia market. Journal of Applied Finance $\mathcal{E}^{\circ}$ Banking, 9(4), 37-45.

Manurung, A. H., \& Manurung, J. C. (2019). Underpricing: Macro economics variables. International Journal of Civil Engineering and Technology, 10(3), 1739-1745.

Mok, H. M., \& Hui, Y. (1998). Underpricing and aftermarket performance of IPOs in Shanghai, China. Pacific-Basin Finance Journal, 6(5), 453-474. Available at: https://doi.org/10.1016/s0927-538x(98)00023-7.

Sudarmaji, E., Ambarwati, S., Hubbansyah, A., \& Shinta, B. (2020). Event study of IPO in Indonesia: Pump-and-Dump \& flipping strategy analysis. Journal of Accounting and Finance Management, 1(1), 81-94. Available at: https://doi.org/10.38035/jafm.v1i1.14.

Tian, L. (2011). Regulatory underpricing: Determinants of Chinese extreme IPO returns. Journal of Empirical Finance, 18(1), 7890. Available at: https://doi.org/10.1016/j.jempfin.2010.10.004.

Vidal-García, J., Vidal, M., \& Nguyen, D. K. (2016). Do liquidity and idiosyncratic risk matter? Evidence from the European mutual fund market. Review of Quantitative Finance and Accounting, 47(2), 213-247. Available at: https://doi.org/10.1007/s11 156-014-0488-7.

Vos, E. A., \& Cheung, J. (1992). New Zealand IPO underpricing: The reputation factor. Small Enterprise Research, 1(1), 13-22. Available at: https://doi.org/10.5172/ser.1.1.13.

\section{Granger Casualty}

Furthermore, to investigated the direction of causality between the cumulative abnormal thirty days (CA30D), the cumulative abnormal five days (CA5D), Inflation (Infaltion), IPO Fund (LnIPOFund), IPO price (lnPrice) and IPO float (lnFloat) in the context of the time-series data. Then the VECM Granger causality equation model can be seen as follows:

$\varnothing$

$$
\begin{aligned}
& \Delta \mathrm{CA} 0 \mathrm{D}_{\mathrm{t}}=\alpha_{1 \mathrm{t}}+\sum^{\mathrm{n}-1} \rho_{1 \mathrm{t}, \mathrm{I}} \Delta \mathrm{CA5D}_{\mathrm{t}-1}+\sum^{\mathrm{n}-1} \beta_{1 \mathrm{t}, \mathrm{I}} \Delta \text { Inflation }_{\mathrm{t}-1}+\sum^{\mathrm{n}-1} \gamma_{1 \mathrm{t}, \mathrm{I}} \Delta \text { InIPOFund }_{\mathrm{t}-1} \\
& +\sum^{\mathrm{n}-1} \delta_{1 \mathrm{t}, \mathrm{l}} \Delta \operatorname{lnPrice} \mathrm{t-1}+\sum^{\mathrm{n}-1} \emptyset_{1 \mathrm{t}, \mathrm{l}} \Delta \operatorname{lnFloat} \mathrm{t}-1_{\mathrm{t}-1}+\mathrm{ECT}_{\mathrm{tt}} \\
& i=1 \quad i=1 \\
& \Delta \mathrm{CA5D}_{\mathrm{t}}=\alpha_{2 \mathrm{t}}+\sum^{\mathrm{n}-1} \rho_{2 \mathrm{t}, \mathrm{l}} \Delta \mathrm{CA} 0 \mathrm{D}_{\mathrm{t}-1}+\sum^{\mathrm{n}-1} \beta_{2 \mathrm{t}, \mathrm{l}} \Delta \text { Inflation }_{\mathrm{t}-1}+\sum^{\mathrm{n}-1} \gamma_{2 \mathrm{t}, \mathrm{l}} \Delta \text { InIPOFund }_{\mathrm{t}-1} \\
& +\sum^{\mathrm{n}-1} \delta_{2 \mathrm{t}, \mathrm{l}} \Delta \operatorname{lnPrice} \mathrm{t}-1+\sum^{\mathrm{n}-1} \emptyset_{2 \mathrm{t}, \mathrm{l}} \Delta \mathrm{InFloat}_{\mathrm{t}-1}+\mathrm{ECT}_{\mathrm{t}-1}+\varepsilon_{2 \mathrm{t}} \\
& \mathrm{i}=1 \mathrm{i}=1
\end{aligned}
$$




$$
\begin{aligned}
& \Delta \text { Inflation }{ }_{\mathrm{t}}=\alpha_{3 \mathrm{t}}+\sum^{\mathrm{n}-1} \rho_{3 \mathrm{t}, \mathrm{l}} \Delta \mathrm{CA} 0 \mathrm{D}_{\mathrm{t}-1}+\sum^{\mathrm{n}-1} \beta_{3 \mathrm{t}, \mathrm{l}} \Delta \mathrm{CA}_{\mathrm{t}-1} \mathrm{i}=1 \mathrm{i}=1+\sum^{\mathrm{n}-1} \gamma_{3 \mathrm{t}, \mathrm{I}} \Delta \mathrm{InIPOFund}_{\mathrm{t}-1} \\
& +\sum^{\mathrm{n}-1} \delta_{3 \mathrm{t}, \mathrm{l}} \Delta \operatorname{lnPrice} \mathrm{t}-1+\sum^{\mathrm{n}-1} \emptyset_{3 \mathrm{t}, \mathrm{l}} \Delta \mathrm{InFloat} \mathrm{t}-1_{\mathrm{t}-1}+\varepsilon_{3 \mathrm{t}}
\end{aligned}
$$

$\mathrm{i}=1 \mathrm{i}=1$

$\Delta \operatorname{lnIPOFund} \mathrm{t}_{\mathrm{t}}=\alpha_{4 \mathrm{t}}+\sum^{\mathrm{n}-1} \rho_{4 \mathrm{t}, \mathrm{I}} \Delta \mathrm{CA30D}_{\mathrm{t}-1}+\sum^{\mathrm{n}-1} \beta_{4 \mathrm{t}, \mathrm{I}} \Delta \mathrm{CA} \mathrm{D}_{\mathrm{t}-1} \mathrm{i}=1 \mathrm{i}=1+\sum^{\mathrm{n}-1} \gamma_{4 \mathrm{t}, \mathrm{l}} \Delta$ Inflation $_{\mathrm{t}-1}$ $+\sum^{\mathrm{n}-1} \delta_{4 \mathrm{t}, \mathrm{l}} \Delta \ln \operatorname{Price} \mathrm{t}-1+\sum^{\mathrm{n}-1} \emptyset_{4 \mathrm{t}, \mathrm{l}} \Delta \operatorname{lnFloat}_{\mathrm{t}-1}+\mathrm{ECT}_{\mathrm{t}-1}+\varepsilon_{4 \mathrm{t}} \mathrm{i}=1 \mathrm{i}=1$

$\mathrm{i}=1 \mathrm{i}=1$

$\Delta \operatorname{lnPrice}{ }_{t}=\alpha_{5 t}+\sum^{n-1} \rho_{5 t, l} \Delta$ CA30D $_{t-1}+\sum^{n-1} \beta_{5 t, l} \Delta$ CA5D $_{t-1} i=1 \quad i=1+\sum^{n-1} \gamma_{5 t, ~} \Delta$ Inflation $_{t-1}$

$+\sum^{\mathrm{n}-1} \delta_{5 \mathrm{t}, \mathrm{l}} \Delta$ InIPOFund $\mathrm{t}-1+\sum^{\mathrm{n}-1} \emptyset_{5 \mathrm{t}, \mathrm{l}} \Delta \mathrm{InFI} \mathrm{oat}_{\mathrm{t}-1}+\mathrm{ECT}_{\mathrm{t}-1}+\varepsilon_{5 \mathrm{t}}$

$i=1 \quad i=1$

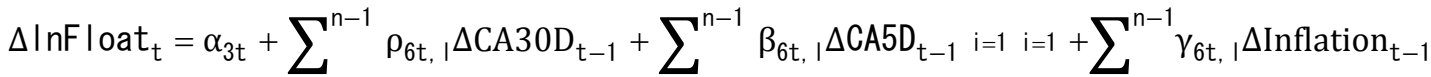

$+\sum^{\mathrm{n}-1} \delta_{6 \mathrm{t}, \mathrm{l}} \Delta$ InIPOFund $\mathrm{t}-1+\sum^{\mathrm{n}-1} \emptyset_{6 \mathrm{t}, \mathrm{l}} \Delta \mathrm{InPr}_{\mathrm{ice}} \mathrm{t-1}+\mathrm{ECT}_{\mathrm{t}-1}+\varepsilon_{6 \mathrm{t}}$

$i=1 \quad i=1$

Where $\mathrm{t}$ is period $(\mathrm{t}=1 \ldots, \mathrm{t})$; $\mathrm{l}$ is lag of each variable; ECT is error correction term and $\varepsilon_{1 \mathrm{t}}, \varepsilon_{2 \mathrm{t}}, \varepsilon_{3 \mathrm{t}}, \varepsilon_{4 \mathrm{I} t}, \varepsilon_{5 \mathrm{t}}, \varepsilon_{6 \mathrm{t}}$, is assuming error rates on the model (error term).

Views and opinions expressed in this article are the views and opinions of the author(s), Financial Risk and Management Reviews shall not be responsible or answerable for any loss, damage or liability etc. caused in relation to/arising out of the use of the content. 